\title{
Upaństwowienie przedszkoli żydowskich w Polsce ,ludowej"1
}

\begin{abstract}
Nationalization of Jewish kindergartens in the Polish People's Republic
Educational and teacher training institutions for Jewish children and adolescents had a long and well-established tradition in Poland. Institutional forms of preschool education call for special attention, all the more so that the remaining national and ethnic minorities did not run their own kindergartens in Poland after WWII. In these circumstances, Jewish kindergartens were a striking exception. Ultimately, they suffered the same fate as the other educational and teacher training institutions managed by entities not welcomed by the Communist party and government in Poland, inspired by Marx's and Lenin's ideologies, whose guidelines from the communist headquarters in Moscow imposed a monopolistic vision of so-called socialist education and upbringing.
\end{abstract}

Keywords: national and ethnic minorities, Jewish education, Jewish kindergartens, nationalization of education, education in the Polish People's Republic

Instytucje oświatowe i opiekuńczo-wychowawcze przeznaczone dla dzieci i młodzieży żydowskiej posiadają na ziemiach polskich długą oraz ugruntowaną tradycję̨2. Doczekały się także znaczących opracowań, w tym dotyczących omawianego okresu. Wymienić tu przede wszystkim należy: monografię Heleny Datner Po zagładzie. Społeczna historia żydowskich domów dziecka, szkót, kót studentów w dokumentach Centralnego

1 Oficjalna nazwa państwa w latach 1947-1952 to Polska Ludowa, a w latach 1952-1989 Polska Rzeczpospolita Ludowa. Celem uproszczenia narracji autor dla obu okresów przyjął nazwę: Polska „ludowa”.

2 Zob. Z. Borzymińska, Szkolnictwo Żydów w Polsce, w: Encyklopedia pedagogiczna XXI wieku, t. VI, red. T. Pilch, Warszawa, 2007, s. 215-229; G. Kawalec, Szkolnictwo żydowskie w Drugiej Rzeczypospolitej (1918-1939), „Rocznik Komisji Nauk Pedagogicznych” 2003, t. 56, s. 33-49. 
Komitetu Żydów w Polsce , opracowanie i wybór tekstów źródłowych zamieszczony w pozycji Dzieje Żydów w Polsce 1944-1968. Teksty źródtowe , publikacje autorstwa Ewy Pogorzały poświęcone problematyce polityki oświatowej władz partyjno-rządowych Polski „ludowej” wobec mniejszości narodowych ${ }^{5}$, czy Grzegorza Berendta Życie żydowskie w Polsce w latach 1950-1956.

Edukacja przedszkolna dzieci żydowskich w pierwszych powojennych dekadach to temat, który dotąd nie został potraktowany odrębnie i opracowany, stąd celem artykułu jest uzupełnienie tej luki przez syntetyczny zarys zagadnienia. Dodać należy, że mniejszości narodowe i etniczne po II wojnie światowej zasadniczo nie prowadziły własnych przedszkoli. Jakiekolwiek formy instytucjonalnego wychowania przedszkolnego dla dzieci mniejszości narodowych i etnicznych zlikwidowane zostały jeszcze w latach 40 . W tym krajobrazie przedszkola żydowskie stanowiły wyjątek, choć ostatecznie podzieliły one los innych placówek, które nie wpisywały się w monopolistyczną wizję systemu oświaty budowanego i dekretowanego przez władze partyjno-rządowe PRL.

Podstawę źródłową opracowania stanowią archiwalia pochodzące z zespołów akt Centralnego Komitetu Żydów w Polsce (CKŻP) oraz Towarzystwa Społeczno-Kulturalnego Żydów w Polsce (TSPŻP). Oba zespoły stanowią własność Archiwum Żydowskiego Instytutu Historycznego im. Emanuela Ringelbluma w Warszawie i są udostępniane badaczom. Istotne dla tematu znaczenie miały również zespoły akt Ministerstwa Oświaty, pochodzące z Archiwum Akt Nowych w Warszawie ${ }^{7}$.

Przechodząc do problemów definicyjnych związanych z tematem, wspomnieć należy, że przedszkola to instytucje opiekuńczo-wychowawcze wspomagające wychowanie dziecka w wieku przedszkolnym, tj. zasadniczo od trzeciego do szóstego roku życia oraz stymulujące jego integralny rozwój, przed wszystkim w obszarze: fizycznym, zdrowotnym, umysłowym, psychicznym, moralnym i estetycznym. Przedszkola stanowią pierwsze ogniwo systemu oświaty i są instytucjami o charakterze propedeutycznym wobec

${ }^{3}$ Zob. H. Datner, Po zagładzie. Spoleczna historia żydowskich domów dziecka, szkót, kót studentów w dokumentach Centralnego Komitetu Żydów w Polsce, Żydowski Instytut Historyczny im. Emanuela Ringelbluma, Warszawa 2016.

${ }^{4}$ A. Cała, H. Datner-Śpiewak (oprac.), Dzieje Żydów w Polsce 1944-1968. Teksty źródtowe, Warszawa 1997.

${ }^{5}$ E. Pogorzała, Mniejszości narodowe i etniczne w polityce oświatowej państwa polskiego w latach 19441966, Państwowa Wyższa Szkoła Zawodowa, Zamość 2009; eadem, Działalność oświatowo-wychowawcza żydowskich kongregacji wyznaniowych $w$ Polsce $w$ drugiej polowie lat 40-tych XX w., „Facta Simonidis. Zeszyty Naukowe Państwowej Wyższej Szkoły Zawodowej w Zamościu" 2008, nr 1, s. 175-190; eadem, Szkolnictwo hebrajskie w Polsce w latach 1946-1949, ,Przegląd Historyczno-Oświatowy” 2006, nr 3/4, s. 137-156; eadem, Problem upaństwowienia szkót Centralnego Komitetu Żydów w Polsce w latach 1945-1949, „Przegląd Historyczno-Oświatowy" 2005, nr 1/2, s.51-68.

${ }^{6}$ Zob. G. Berendt, Życie żydowskie w Polsce w latach 1950-1956, Gdańsk 2006, s. 214-231.

${ }^{7}$ Na temat źródeł do historii Żydów w Polsce przechowywanych w Archiwum Akt Nowych w Warszawie szerzej zob. A.G. Dąbrowski, Źródła do dziejów społeczności żydowskiej w Polsce w zasobie Archiwum Akt Nowych, w: Źródła archiwalne do dziejów Żydów w Polsce, red. B. Woszczyński, V. Urbaniak, Warszawa 2001, s. 57-70. 
szkoły ${ }^{8}$. Oprócz przedszkoli właściwych wyróżnia się inne placówki wychowania przedszkolnego. Są to formy o prostszej strukturze organizacyjnej, niezobligowane do realizacji ministerialnego programu wychowania przeznaczonego dla przedszkoli właściwych i obsadzone zasadniczo słabiej wykwalifikowaną kadrą kierowniczą oraz wychowawczą. W polskiej historiografii edukacyjnej na określenie prostszych placówek opiekuńczo-wychowawczych dla dzieci w wieku przedszkolnym przyjęło się różne nazewnictwo, w zależności od prowadzonej w nich działalności, np. ochronki, dziecińce, przystanie. Uproszczone formy wychowania przedszkolnego zasadniczo nie były objęte dokładną ewidencją państwową. $Z$ racji przewagi w nich funkcji o charakterze opieki wychowawczej, placówki te często podlegały pod resort właściwy do spraw opieki społecznej. W okresie powojennym, wbrew obowiązującym przepisom prawa oświatowego i ich urzędowej wykładni, prostsze placówki wychowania przedszkolnego podporządkowane zostały Ministerstwu Oświaty ${ }^{9}$, które dążyło do uzyskania monopolu w zakresie instytucjonalnego wychowania dziecka od trzeciego roku życia, w celu poddania obywateli oddziaływaniom ideologii komunistycznej od najmłodszych lat ${ }^{10}$.

Wśród placówek wychowania przedszkolnego działających na ziemiach polskich wyodrębnić należy przedszkola przeznaczone dla mniejszości narodowych i etnicznych, w tym przedszkola żydowskie. Status i działalność placówek oświatowo-wychowawczych dla dzieci mniejszości żydowskiej w wieku przedszkolnym uregulowane zostały w prawodawstwie polskim w okresie II Rzeczypospolitej. Przedszkola żydowskie podlegały ustawie z 11 III 1932 r. o prywatnych szkołach i zakładach naukowych i wychowawczych ${ }^{11}$. Zakwalifikowanie przedszkoli żydowskich do placówek prywatnych rozumieć należy w znaczeniu ustawy z 11 marca 1932 r. o ustroju szkolnictwa. W świetle ustawy szkolnej przedszkola prywatne były przedszkolami innymi niż państwowe, tzn. utrzymywane wyłącznie przez państwo oraz innymi niż publiczne, tzn. utrzymywane przez państwo wspólnie z samorządem terytorialnym lub gospodarczym. Wszystkie pozostałe przedszkola objęte zostały regulacjami dotyczącymi placówek prywatnych $^{12}$. Zwrócić należy tu przy tym uwagę, że dzieci żydowskie objęte były nie tylko strukturami szkolnymi dla mniejszości narodowych. Zdecydowana większość rodziców spośród Żydów, mimo protestów organizacji żydowskich, wybierała dla swych

${ }^{8}$ Por. K. Kamińska, Przedszkola, w: Encyklopedia pedagogiczna XXI wieku, t. IV, red. T. Pilch, Wydawnictwo Akademickie „Żak”, Warszawa 2005, s. 1020.

${ }^{9}$ Ustawa z 7 kwietnia 1949 r. o przekazaniu ministrowi oświaty zakresu działania ministra pracy i opieki społecznej w przedmiocie opieki społecznej nad dziećmi i młodzieżą, Dz.U. 1949, nr 25, poz. 175.

${ }_{10}$ Szerzej zob. J. Wiśniewska, Przedszkola i ochronki zakonne w świetle polskiego prawa oświatowego w latach 1945-1961, „Studia z Prawa Wyznaniowego” 2015, t. 18, s. 315-319.

11 Ustawa z 11 marca 1932 r. o prywatnych szkołach i zakładach naukowych i wychowawczych, Dz.U. 1932, nr 33, poz. 343; H. Seidman (zbiór i oprac.), Żydowskie szkolnictwo religijne w ramach ustawodawstwa polskiego, Warszawa 1937.

12 Ustawa z 11 marca 1932 r. o ustroju szkolnictwa, Dz.U. 1932, nr 38, poz. 389. 
dzieci ogólnie dostępne placówki publiczne, przede wszystkim dlatego, że były bezpłatne ${ }^{13}$.

W okresie II Rzeczypospolitej oświata mniejszości narodowych, w tym mniejszości żydowskiej uległa znaczącym przekształceniom. Cezurę stanowi tu wprowadzenie obowiązku szkolnego, co wymusiło modernizację dotychczasowych form i instytucji, jak tradycyjnych chederów. Zaostrzone również zostały kryteria zatrudnienia nauczycieli przedmiotów świeckich w placówkach zakładanych przez prywatne - w rozumieniu ustawy szkolnej - podmioty prowadzące. W przypadku mniejszości żydowskiej były to silnie zróżnicowane politycznie i światopoglądowo organizacje świeckie i wyznaniowe oraz partie polityczne. Dla przykładu podać można, że w 1937 r. tylko pod patronatem Agudy działało 818 instytucji edukacyjnych dla 109 tys. dzieci i młodzieży. Osiągnięciem organizacyjnym w zakresie oświaty żydowskiej było powołanie w 1921 r. Centralnej Żydowskiej Organizacji Szkolnej (CISZO). Dominujące wpływy w niej zdobyła partia robotnicza Bund. CISZO w roku szkolnym 1928/1929 dysponowała 114 szkołami powszechnymi, nie licząc innych obiektów edukacyjnych i wychowawczych. Z czasem silny rozwój liczebny CISZO został zahamowany na skutek braku dostatecznych źródeł finansowania. Organizacja Szuł-Kult na początku lat 30. uruchomiła 52 szkoły powszechne i przedszkola obejmujące edukacją i wychowaniem 6519 dzieci pochodzenia żydowskiego. Biorąc pod uwagę tylko przytoczone tu przykładowe przecież dane, stwierdzić należy, że mimo trudności wewnętrznych, polegających zwłaszcza na silnym rozdrobnieniu i podziałach panujących w społeczności żydowskiej oraz ciągłej walki o pozyskanie niezbędnych środków materialnych, uznać należy, że szkolnictwo żydowskie w okresie międzywojennym odniosło stosunkowo duże sukcesy w zakresie sieci i liczby założonych oraz prowadzonych placówek edukacyjnych i wychowawczych ${ }^{14}$. Zaliczyć do nich można również skromną $\mathrm{w}$ porównaniu do szkół, których udział procentowy jest $\mathrm{w}$ tendencjach ogólnych znacząco wyższy, odrębną sieć przedszkoli żydowskich i pozostałych placówek wychowania przedszkolnego. Według danych statystycznych GUS na terytorium II Rzeczypospolitej działało w 1937 r. 40 przedszkoli właściwych, w których nauczanie i wychowanie odbywało się w języku hebrajskim ${ }^{15}$.

Po tragedii II wojny światowej ocalała z zagłady, lecz zdziesiątkowana i wyniszczona zdrowotnie, moralnie i materialnie społeczność żydowska podjęła heroiczny wysiłek reaktywacji placówek instytucjonalnej edukacji, wychowania i opieki nad dzieckiem żydowskim $^{16}$. Nie sprzyjała temu koncepcja homogenicznej narodowościowo Polski „ludowej”, dla władz której ideałem było państwo jednolite etnicznie. Będąca u steru rządu partia komunistyczna PPR/PZPR dopuszczała istnienie zjawiska mniejszości narodo-

${ }^{13}$ K. Zieliński, Szkolnictwo żydowskie w Polsce w latach 1918-1939, „Almanach Historyczny” 2003, t. 5, s. 216.

14 Z. Borzymińska, op. cit., s. 215-229.

15 Ibidem, s. 215-229.

16 Ibidem. 
wych, ale jedynie w kategoriach instrumentalnego wykorzystania politycznego, w tym legitymizacji nowych władz i budowniczych nowego ustroju ${ }^{17}$. Polityka narodowościowa i etniczna oparta była na założeniach marksistowsko-leninowskich, interpretowanych na bieżąco przez przywódców komunistycznych PPR/PZPR, podległych wytycznym Moskwy, rozumianej jako centrala komunistyczna. Uwarunkowania polityczne przekładały się na sferę oświatową i wychowawczą ${ }^{18}$. W polityce edukacyjnej oznaczały przyjęcie kierunku asymilacyjnego wobec wychowanków narodowości i pochodzenia niepolskiego, szczególnie przez ograniczanie i praktyczną likwidację wolnego szkolnictwa mniejszościowego. Wyrazem praktycznym przyjętych założeń była przymusowa polonizacja dzieci ludności autochtonicznej, likwidacja szkolnictwa mniejszościowego, ekspatriacja z terytorium polskiego nauczycieli ukraińskich, białoruskich, niemieckich, czy słowackich, w przypadku mniejszości żydowskiej odmowa finansowania szkół mniejszościowych ze środków publicznych, odmowa nadania uprawnień szkół publicznych placówkom prywatnym, jak w przypadku szkół hebrajskich, bierna akceptacja faktów takich jak ten, że w przypadku mniejszości niemieckiej część dzieci faktycznie nie realizowała obowiązku szkolnego, a niektóre formy oświaty mniejszościowej nie dawały wykształcenia tożsamego z edukacją w szkole publicznej, jak w przypadku chederów ${ }^{19}$. Dodać należy, że pozbawione przysługującej autonomii szkolnictwo mniejszościowe na przełomie lat 40. i 50. XX w. poddane zostało silnemu upolitycznieniu oraz ideologizacji we wszystkich aspektach działalności poszczególnych instytucji, to jest: programowym, organizacyjnym, kadrowym i wychowawczym. Władze partyjno-rządowe doprowadziły do rzeczywistego przejęcia placówek mniejszościowych przez państwo, a o ich charakterze i programie rozstrzygać miała odtąd partia komunistyczna ${ }^{20}$. Zwrócić należy tu uwagę, że wydawane przez władze Polski „ludowej” przepisy oświatowe, regulujące działalność placówek mniejszościowych nie musiały oznaczać faktycznego ich istnienia, jak w przypadku np. przedszkoli dla mniejszości niemieckiej, które istniały jedynie na papierze, to jest $\mathrm{w}$ ministerialnych planach i regulacjach ${ }^{21}$.

Okres odwilży politycznej przyniósł złudne nadzieje na odnowienie aktywności mniejszości narodowych i etnicznych na polu oświaty. Zakładano liczne towarzystwa społeczno-kulturalne, jak określano: narodowe w formie, a socjalistyczne w treści, aspirujące do odegrania większej roli i zmierzające do poszerzania dotychczasowych możliwości i wpływów mniejszości narodowych w przestrzeni publicznej, w tym oświatowej. Faktycznie jednak ich działalność sprowadzona została do folkloru. Towarzystwa nie

\footnotetext{
17 Por. G. Berendt, Życie żydowskie w Polsce..., s. 81; P. Kendziorek, Program i praktyka produktywizacji Żydów polskich $w$ działalności CKŻP, Żydowski Instytut Historyczny im. Emanuela Ringelbluma, Warszawa 2016, s. 83-84.

${ }^{18}$ E. Pogorzała, op. cit., s. 35.

19 Ibidem, s. 36-37.

20 Ibidem, s. 37.

${ }^{21}$ Instrukcja ministra oświaty w sprawie otwarcia przedszkoli i szkół ogólnokształcących z niemieckim językiem nauczania, Dz.Urz. M.Ośw. 1950, nr 14, poz. 177.
} 
uzyskały podmiotowości pozwalającej na samodzielną wobec PZPR działalność w obrębie szkolnictwa mniejszościowego ${ }^{22}$.

Ministerstwo Oświaty w 1957 r. opracowało perspektywiczny plan pracy resortu w zakresie realizacji wniosków Komisji KC PZPR ds. Narodowościowych w kwestii rozwoju szkolnictwa dla mniejszości narodowych w Polsce, w tym opracowanie zasad organizacji przedszkoli mniejszościowych, zapewnienie im kadry, a następnie uruchomienie $^{23}$. Zofia Woźnicka, dyrektor departamentu ds. przedszkoli w Ministerstwie Oświaty uwzględniła w projekcie równie prostsze formy wychowania przedszkolnego, takie jak grupy przedszkolne przy szkołach mniejszości narodowych, żłobko-przedszkola, ogniska dziecięce itp. Doskonalenie rozwiązań prawnych w realiach PRL nie przekładało się jednak na rozwój rzeczywistego, autonomicznego szkolnictwa mniejszościowego ${ }^{24}$.

Dla społeczności żydowskiej istotne znaczenie miała jeszcze jedna cezura. Wskutek konfliktów frakcji wewnątrzpartyjnych w PZPR, doszły do głosu antysemickie resentymenty, inspirowane przez frakcję partyzantów i ich przywódcę Mieczysława Moczara, który od 1964 r. postulował eliminację z kierownictwa PZPR Żydów i osób żydowskiego pochodzenia. Nie pozostało to bez negatywnego wpływu na dzieci i młodzież żydowską objętą polskim systemem oświaty i wychowania ${ }^{25}$.

Powojenna sytuacja dzieci żydowskich w wieku przedszkolnym była niezwykle trudna. W perspektywie porównawczej uznać należy, że ogólnie los dzieci w wieku przedszkolnym w pierwszych latach po II wojnie światowej, niezależnie od przynależności narodowościowej, był wyjątkowo ciężki, zwłaszcza tych, które straciły rodziców, pozostawały sierotami lub półsierotami. $Z$ tego powodu najważniejszą aktywnością przedszkoli w okresie powojennym była akcja ratownictwa życia i zdrowia wychowanków, przez organizowanie im dożywiania, zapewnienia opieki, a także - w miarę możliwości - pomocy medycznej i materialnej. W powojenne ratownictwo dzieci własnej narodowości włączyła się ocalała społeczność żydowska, która podjęła akcję w trosce o przetrwanie i przyszłość narodu żydowskiego. H. Datner, powołując się na źródła Archiwum Żydowskiego Instytutu Historycznego im. Emanuela Ringelbluma w Warszawie w publikacji dotyczącej historii społecznej ocalałych z Holacaustu Żydów w Polsce, przytoczyła szacunkowe dane statystyczne na temat demografii dzieci żydowskich na terenie kraju. Odnotowała, że w momencie zakończenia wojny w granicach polskich przebywało niecałe 4 tys. dzieci żydowskich. Pod koniec 1945 r. było ich już ok. 5 tys. Poważną grupę

${ }^{22}$ Archiwum Akt Nowych w Warszawie (AAN), Ministerstwo Oświaty (M.Ośw.), 1750, Uwagi do projektu planu pracy w zakresie szkolnictwa dla mniejszości narodowych, Warszawa, 18 listopada 1957 r., k. 15.

23 AAN, M.Ośw., 1750, Perspektywiczny plan pracy M.Ośw. w zakresie realizacji wniosków komisji KC PZPR ds. narodowościowych w sprawie rozwoju szkolnictwa dla mniejszości narodowych w Polsce, 1957 r., k. 17-23.

${ }^{24}$ AAN, M.Ośw., 1750, Uwagi do projektu planu pracy w zakresie szkolnictwa dla mniejszości narodowych, Warszawa, 18 listopada 1957 r., k. 15.

${ }^{25}$ E. Pogorzała, op. cit., s. 39-40; G. Pańko, M. Skotnicka-Palka, B. Techmańska (red.), Młodzież w perspektywie edukacyjnej, społecznej i kulturowej, Wrocław 2004, s. 99. 
wśród najmłodszych Żydów stanowiły dzieci w wieku do lat czternastu repatriowane z ZSRR, których z kolei liczbę szacuje się na ok. 30 tys. ${ }^{26}$ Duży procent najmłodszego pokolenia Żydów stanowiły dzieci osierocone lub półsieroty. Dość wspomnieć, że jedynie ok. 5\% dzieci żydowskich uratowanych w Polsce miało oboje rodziców. Sierot było natomiast 58\%. Wśród dzieci repatriantów 1/3 dzieci miało oboje rodziców, natomiast $27 \%$ pozostawało sierotami ${ }^{27}$.

Zjawisko sieroctwa skłoniło społeczność żydowską do zakładania przede wszystkim placówek opieki zamkniętej, w których sieroty można było otoczyć podstawową opieką. Potrzeba ta zapoczątkowała działalność powojennych domów dziecka, których w $1946 \mathrm{r}$. działało 13, obejmując opieką 866 dzieci. Dodatkowo, z powodu złego stanu zdrowia dzieci, mniejszość żydowska uruchamiała własne zakłady leczniczo-wychowawcze przeznaczone dla dzieci. Dzieci żydowskie w wieku przedszkolnym, również te przebywające w domach dziecka, uczęszczały do przedszkoli żydowskich ${ }^{28}$, które organizowano w myśl zasady, że tylko we własnej, narodowościowej placówce oświatowej dziecko mogło zostać wychowane w duchu rodzimej kultury i tradycji ${ }^{29}$. Od 1944 r. do końca lat 40. przedszkola żydowskie były przez władze partyjno-rządowe w Polsce uznawane za placówki prywatne, w rozumieniu ustawy z 1932 r. ${ }^{30}$ Pierwsze lata ich funkcjonowania pozostawiły ślad w dokumentacji sprawozdawczej struktur żydowskich, a także we wspomnieniach. Przede wszystkim dzieci żydowskie przebywające w placówkach opiekuńczo-wychowawczych, w tym w przedszkolach obciążone były doświadczeniem wojny i Holocaustu, co nie pozostawało bez wpływu na ich psychikę oraz sposób funkcjonowania w placówce, która w dodatku daleka była od przedszkola wzorcowego. Jak czytamy w przykładowych wspomnieniach:

przedszkole z dniem 18 sierpnia 1947 roku zorganizowat Komitet Żydów Polskich przy ul. Kottątaja 13 [w Szczecinie]. Kierowniczka została Helena Rizenbaum. Warunki lokalowe tego przedszkola były bardzo trudne, uczęszczające do niego dzieci wymagaty dużo ciepła, troski $i$ opieki. Zarówno dzieci, jak i rodzice byli wyjątkowo niedożywieni, chorowici i znerwicowani, co spowodowane było dtuższym ukrywaniem się w czasie okupacji, z której cudem ocaleli ${ }^{31}$.

W 1946 r. wychowaniem przedszkolnym w tego typu placówkach objętych zostało 237 dzieci żydowskich. Spośród pozostałych form wychowania przedszkolnego istotną w tym okresie rolę odegrały półinternaty przedszkolne, których celem statutowym była opieka nad dzieckiem pracujących rodziców. W półinternatach przedszkolnych dzieci

${ }^{26}$ H. Datner, op. cit., s. 25.

27 Ibidem.

${ }_{28}$ Archiwum Żydowskiego Instytutu Historycznego (AŻIH), Centralny Komitet Żydów w Polsce (CKŻP), 303/IX/9, Sprawozdanie Wydziału Opieki nad Dzieckiem CKŻP, 1946 r., k. 32-35.

${ }_{29}$ J. Kwiek, Żydzi, Łemkowie, Słowacy w województwie krakowskim w latach 1945-1949/50, Kraków 2002, s. 159.

${ }^{30}$ A. Grabski, Centralny Komitet Żydów w Polsce (1944-1950). Historia polityczna, Warszawa 2015, s. 9.

${ }^{31}$ G. Hrycyna, op. cit., s. 577; por. H. Mirska Lasota, Ucieczka od przeszłości, Montreal 2006. 
przebywały od godz. 9.00 do 17.00 . W placówkach posługiwano się zasadniczo, podobnie jak w przedszkolach właściwych, językiem polskim oraz jidysz ${ }^{32}$. W instrukcji CKŻP na temat prowadzenia półinternatów przedszkolnych przebijała troska społeczności żydowskiej o zachowanie tożsamości oraz integrację grupy narodowościowej. Zalecano dodatkowo, by tam, gdzie nie udało się założyć półinternatu, gromadzić okresowo dzieci na pogadanki oraz umożliwić im udział w wydarzeniach kulturalnych wpływających na większą identyfikację narodową. Działalność żydowskich placówek przedszkolnych była ewidencjonowana i podlegała kontroli przedstawicieli Wydziału Oświaty CKŻ $\mathrm{P}^{33}$ pod względem pracy wychowawczej prowadzonej w placówce, metodycznym, administracyjnym oraz sanitarnym. Przeprowadzone kontrole miały charakter gruntowny ${ }^{34}$. Wizytatorzy badali znajomość języka hebrajskiego u podopiecznych, a także ich wygląd: czy były zdrowe, dobrze odżywione, zadbane i czy nosiły odpowiednie ubrania. Ponadto interesowano się nie tylko kwalifikacjami, ale i stanem materialnym kadr pedagogicznych ${ }^{35}$.

Placówki opiekuńczo-wychowawcze dla dzieci żydowskich działały nie tylko w oparciu o odgórne regulacje władz państwowych, lecz także przepisy wewnętrze, przede wszystkim statuty i regulaminy. Statut przedszkola CKŻP określał, że przedszkole żydowskie miało za zadanie roztoczenie troskliwej i umiejętnej opieki nad zdrowiem oraz rozwojem fizycznym, umysłowym i moralnym dzieci w wieku przedszkolnym. W myśl statutu przedszkole organizowane było jako placówka koedukacyjna. Podczas zajęć korzystano z pomocy pedagogicznych zatwierdzonych przez polskie władze oświatowe ${ }^{36}$. Ponadto sformułowane zostały wytyczne ideologiczno-wychowawcze dla przedszkoli półinternatowch, obowiązujące również w innych placówkach opiekuńczych CKŻP. Nawiązywały one m.in. do tradycji ruchu robotniczego: a) wychowanie do poczucia własnej godności, do zrozumienia dla „ogólnoludzkich idei demokracji, postępu i braterstwa ludowego” oraz „związku z Międzynarodowym Światem Pracy, walczącym o wyzwolenie społeczne"; b) wychowanie dzieci do pozytywnego i serdecznego stosunku oraz przywiązania do odrodzonej „Polski Demokratycznej”; c) pielęgnowanie poczucia godności narodowej, umiłowania dla języka, literatury i historii Żydów, poczucia związku z narodem żydowskim na całym świecie, w szczególności z jego „demokratycznymi, postępowymi czynnikami, walczącymi o narodowe i społeczne wyzwolenie mas żydowskich"; d) zaszczepienie dzieciom zasad etyki społecznej, odpowiedzialności za słowa i czyny, solidarności zbiorowej oraz altruizmu ${ }^{37}$.

${ }^{32}$ AŻIH, CKŻP, 303/IX/9, Sprawozdanie Wydziału Opieki nad Dzieckiem CKŻP, 1946 r., k. 35-37.

${ }^{33}$ AŻ̇H, CKŻP, 303/IX/7, Wytyczne dla inspektorów półinternatów CKŻP, b.d., k. 2.

${ }^{34}$ AŻ̇H, CKŻP, 303/IX/7, Wytyczne dla inspektorów pólinternatów CKŻP, b.d., k. 2.

${ }^{35}$ AŻIH, CKŻP, 303/IX/7, Instrukcje dla inspektorów-instruktorów szkolnych WO CKŻP, Warszawa, 10 stycznia 1947 r., k. 13.

${ }^{36}$ AŻIH, CKŻP, 303/IX/95, Statut przedszkola CKŻP, b.d., k. 1.

${ }^{37}$ AŻIH, CKŻP, 303/IX/4, Wytyczne Referatu Opieki Nad Dzieckiem CKŻP ideologiczno-wychowawcze dla Zakładów Opieki nad Dzieckiem CKŻP, Warszawa, 10 lipca 1945 r., k. 15. 
Stan materialny przedszkoli i innych placówek wychowania przedszkolnego, jak już wspomniano, był zasadniczo bardzo trudny. Wizytatorzy z ramienia CKŻP oceniali, że w niektórych miejscowościach zachodziła stopniowa poprawa warunków lokalowych, sanitarnych oraz zdrowotnych. Odnotowywano dobre wyniki pracy personelu pedagogicznego, jak w przedszkolu w Łodzi ${ }^{38}$. Nie wszędzie jednak panował odpowiedni poziom. Przykładem może tu być półinternat w Kamiennej Górze, gdzie lokal przeznaczony dla dzieci żydowskich oceniono jako nieestetyczny, ponury i wilgotny. Sprawę dodatkowo pogarszał fakt, że wychowawczynie nie miały kwalifikacji do pracy w przedszkolu, którą zresztą wykonywały niechętnie. W placówce nie było żadnych zabawek, a opieka lekarska pozostawiała wiele do życzenia ${ }^{39}$. Niektóre placówki borykały się z wielkim ubóstwem swych podopiecznych pozbawionych obuwia, ubrań zimowych czy zmiany bielizny. W przedszkolach dzieci zarażały się chorobami zakaźnymi, świerzbem i wszawicą ${ }^{40}$. Odnotowywano „opłakany” stan obiektów, które nie zawsze posiadały kanalizację, w związku z czym dzieci ,załatwiały swoje potrzeby w pokojach" ${ }^{41}$. Pamiętać przy tym należy, że przedszkola żydowskie nie należały w tym aspekcie do wyjątków. $\mathrm{W}$ pierwszych latach powojennych bardzo trudne warunki istniały również w wielu pozostałych placówkach opiekuńczo-wychowawczych, a dzieci w wieku przedszkolnym przebywające w domach dziecka, niezależnie od narodowości i pochodzenia, należały do najbardziej zaniedbywanej grupy wiekowej ${ }^{42}$.

Działacze oświatowi mniejszości żydowskiej, reagując na piętrzące się jeszcze w 1947 r. trudności w przedszkolach, debatowali nad koniecznością podniesienia poziomu pracy placówek adresowanych dla dzieci żydowskich w wieku przed podjęciem obowiązku szkolnego. Wnioskowano urządzenie kursu dla wychowawczyń oraz wyasygnowanie na ten cel konkretnych środków ${ }^{43}$. W prezydium CKŻP zasiadali wówczas przedstawiciele zróżnicowanych ugrupowań politycznych Żydów, z PPR, Bund, organizacji syjonistycznych. Wśród wymienionych podmiotów, charakteryzujących się poważną rozpiętością w sferze światopoglądowej i politycznej, dochodziło do poważnych napięć $^{44}$. W przestrzeni oświatowej i opiekuńczo-wychowawczej konflikty wybuchały na

38 AŻIH, CKŻP, 303/IX/21, Sprawozdanie z wizytacji przedszkola im. Szolem Alejchema w Łodzi, 25-28 lutego 1947 r., k. 2.

39 AŻIH, CKŻP, 303/IX/22, Sprawozdanie z inspekcji półinternatu żydowskiego w Kamiennej Górze, sierpień 1947 r., k. 7.

40 AŻIH, CKŻP, 303/IX/22, Protokół wizytacji na Dolnym Śląsku, 29 grudnia 1946 - 9 I 1947 r., k. 24.

${ }^{41}$ AŻIH, CKŻP, 303/IX/22, Pismo Towarzystwa Ochrony Zdrowia przy CKŻP do WO CKŻP, Łódź, 31 stycznia 1947 r., k. 31.

42 „,Lazienki, ubikacje i obejście zanieczyszczone. Ogród zaniedbany. [...] Odzież dzieci zaniedbana. Pościel brudna. Przy myciu wieczornym dzieci nie ma kontroli. Złe podejście wychowawcze dzieci, gdyż publicznie karze się dzieci chłostą, lub klęczeniem w sali, czy na podwórku za małe przewinienia, jest na porządku dziennym. Dzieciom nie przemawia się do ambicji”. AAN, CKOS, 103, A. Jonczyk, inspektor CKOS, Sprawozdanie z lustracji Domu Dziecka w Biesalu, Olsztyn, 27 sierpnia 1947 r., k. 233.

43 AŻIH, CKŻP, 303/IX/8, Protokół zebrania pracowników WO CKŻP, 10 lutego 1947 r., k. 2-3.

44 Szerzej zob. A. Grabski, op. cit. 
tle kierunku wychowania dzieci żydowskich. Główna linia sporu przebiegała na osi emigracji bądź pozostania w Polsce, co zasadniczo wpływało na rozumienie założeń programowych wychowania dziecka żydowskiego. Między partiami religijnymi, które działały niezależnie od CKŻP - konflikt o los dziecka nie uwidaczniał się tak jaskrawo, jak w przypadku ugrupowań syjonistycznych. Działacze syjonistyczni z kolei zaszczepiali w wychowankach myśl, że w Polsce przyszłość dla Żydów nie istniała ${ }^{45}$. Rywalizacja wewnętrzna o dziecko żydowskie i jego wychowanie przybrała z czasem na sile ${ }^{46}$.

Placówki przedszkolne CKŻP choć miały charakter całkowicie świecki, zachowały pewne zwyczaje nawiązujące do judaizmu. Sobota pozostała dniem odpoczynku. W placówkach CKŻP obchodzone były święta żydowskie, ale pozbawiono je wydźwięku religijnego ${ }^{47}$.

Pod koniec lat 40. władze partyjno-rządowe w porozumieniu z CKŻP położyły kres względnej autonomii przedszkoli żydowskich. W 1949 r., gdy CKŻP całkowicie zdominowany został przez żydowskich działaczy komunistycznych, przedszkola Komitetu, których do 1949 r. działało jeszcze 34, poddano upaństwowieniu. Przejęcie przedszkoli żydowskich przez państwo oznaczało finał prowadzonych przez kilkanaście miesięcy negocjacji przedstawicieli CKŻP z Ministerstwem Oświaty ${ }^{48}$. Należy tu dodać, że do upaństwowienia zmierzały nie tylko resort oświatowy. Było to również dążenie CKŻP, który w ten sposób chciał uchronić oświatowe i wychowawcze placówki żydowskie przed z jednej strony zamknięciem, spowodowanym chociażby brakiem środków na ich prowadzenie, z drugiej natomiast - przed utratą praw publicznych. Uważano, że upaństwowienie nada szkolnictwu żydowskiemu ten sam status, co szkołom państwowym. $Z$ tego powodu - jak się wydaje - upaństwowienie szkolnictwa żydowskiego nazwane zostało przez H. Datner dobrodziejstwem ${ }^{49}$. Upaństwawiane przedszkola żydowskie ulokowane były w następujących miejscowościach: w Warszawie - 2, w Łodzi - 3, na Pomorzu - 1, w Szczecinie - 4, we Wrocławiu - 21, na Śląsku - 2 i w Krakowie - 1. Po nieodpłatnym przejęciu placówek przez władze oświatowe z dniem 1 stycznia 1950 r., przekazane zostały pod władzę partyjno-państwowej administracji terenowej oraz podlegały kontroli lokalnych inspektorów szkolnych ${ }^{50}$. Oprócz wymienionych przedszkoli, upaństwowionych zostało jeszcze 19 szkół żydowskich, w tym 16 podstawowych oraz 8 żydowskich

${ }^{45}$ M. Rusiniak-Karwat, Nowe życie na zgliszczach. Bund w Polsce w latach 1944-1949, Instytut Studiów Politycznych PAN, Warszawa 2016, s. 52-53; N. Bażanowska, op. cit., s. 56.

${ }^{46}$ Ibidem, s. 55; Dzieje Żydów w Polsce 1944-1968. Teksty źródłowe, oprac. A. Cała, H. Datner-Śpiewak, Warszawa 1997, s. 221-223.

47 N. Bażanowska, op. cit., s. 57.

${ }_{48}$ AAN, M.Ośw., 1469, Juriewicz, Pismo do Kancelarii Rady Państwa w sprawie upublicznienia 34 przedszkoli CKŻP, Warszawa, 8 listopada 1949 r., k. 191-192; G. Berendt, Życie żydowskie w Polsce w latach 1950-1956. Z dziejów Towarzystwa Społeczno-Kulturalnego Żydów w Polsce, Gdańsk 2006, s. 215.

49 H. Datner, op. cit., s. 80-81.

${ }^{50}$ AŻIH, CKŻP, 303/IX/36, Pismo M.Ośw. do KOS na terenie kraju, Warszawa, grudzień 1949 r., k. 10. 
domów dziecka ${ }^{51}$. CKŻP został natomiast zlikwidowany. Na miejsce CKŻP jeszcze w tym samym roku powołane zostało koncesjonowane przez komunistów Towarzystwo Społeczno-Kulturalne Żydów w Polsce (TSKŻP), które stało się jedyną świecką organizacją Żydów polskich, działającą do końca PRL. Jej zadaniem była m.in. troska o wychowanie przedszkolne żydowskich dzieci, przy czym statut TSKŻP wyraźnie nawiązywał do założeń ideologicznych organizacji odpowiadających realiom Polski „ludowej”. Ponadto towarzystwo nie pełniło roli podmiotu prowadzącego przedszkole, jak wcześniej CKŻP, ale jedynie tzw. czynnika współdziałającego z nowym podmiotem prowadzącym placówkę ${ }^{52}$ W okresie realizacji planu sześcioletniego TSKŻP deklarowało przeprowadzanie systematycznej pracy uświadamiającej wśród matek niepracujących, by zdecydowały się na podjęcie pracy zawodowej, a w przypadku braku z ich strony zainteresowania, zalecano, by „planowo i systematycznie usunąć” ich dzieci z przedszkoli. W celu dostosowania przedszkoli do zadań planu gospodarczego TSKŻP nakazało przeprowadzenie komasacji dzieci, aby można było ich jak najwięcej przyjąc ${ }^{53}$. W okresie realizacji planu sześcioletniego dzieci żydowskie uczęszczały do przedszkoli razem z dziećmi polskimi ze względu na obowiązek przyjmowania do placówki dzieci z rejonu. Proporcje jednej i drugiej narodowości kształtowały się bardzo różnie. Do przedszkola w Bielawie uczęszczało 70 dzieci żydowskich, natomiast 21 polskich, w przedszkolu nr 18 we Wrocławiu na 145 dzieci żydowskich, przypadało tylko 5 polskich, w Kłodzku natomiast więcej było dzieci polskich -60 , a mniej żydowskich $-24^{54}$. Do przedszkoli w Łodzi, podległych wcześniej CKŻP, uczęszczało 204 dzieci żydowskich, natomiast 60 polskich $^{55}$.

Powojenny proces przebudowy oświaty polskiej w oparciu o ideologiczne założenia oraz sytuujący przedszkola w systemie szkolnym PRL zadekretowany został ustawowo w $1961 \mathrm{r} .{ }^{56} \mathrm{~W} 1965 \mathrm{r}$. natomiast Ministerstwo Oświaty wydało akt wykonawczy do wspomnianej ustawy, tj. zarządzenie ministra oświaty $\mathrm{w}$ sprawie statutu przedszkola, uszczegóławiające postanowienia ustawy w odniesieniu do przedszkoli i stanowiące zarazem dokument podstawowej wagi dla funkcjonowania tego typu placówek ${ }^{57}$. Wspomnieć tu należy, że również w 1965 r. ukazało się zarządzenie ministra oświaty w sprawie zasad i warunków prowadzenia niepaństwowych szkół i innych placówek oświatowo-wychowawczych jako odpowiedź na ratyfikowaną przez Polskę 16 września

${ }^{51}$ H. Datner, op. cit., s. 85.

${ }^{52}$ A. Grabski, op. cit., s. 249-251, 255; Statut Towarzystwa Społeczno-Kulturalnego Żydów w Polsce, Warszawa 1959.

53 AŻIH, Towarzystwo Społeczno-Kulturalne Żydów w Polsce (TSKŻP), 325/107, Plan pracy WO na II kwartał 1951 r., k. 6.

${ }^{54}$ AŻIH, TSKŻP, 325/116, Wykaz przedszkoli z dziećmi żydowskimi, b.d., b.p.

${ }^{55}$ AŻIH, TSKŻP, 325/116, Pismo z oddziału TSPŻ w Łodzi do WO ZG TSKŻ, 23 maja 1951 r., b.p.

${ }^{56}$ Ustawa z 15 lipca 1961 r. o rozwoju systemu oświaty i wychowania. Dz.U. 1961, nr 32, poz. 160.

57 Zarządzenie ministra oświaty z 15 II 1965 r. w sprawie statutu przedszkola podległego Ministerstwu Oświaty, Dz.Urz. M.Ośw. 1965, nr 6, poz. 46. 
1964 r. międzynarodową konwencję UNESCO w sprawie zwalczania dyskryminacji w dziedzinie oświaty z 15 grudnia 1960 r. ${ }^{58}$ Zarządzenie stwarzać miało wrażenie wolności zakładania placówek oświatowo-wychowawczych przez podmioty pozapaństwowe, które w rzeczywistości jednak ograniczono do partyjnych koncesjonariuszy, a pozostałe praktycznie wyeliminowano z systemu oświaty. Ustawodawstwo 1. poł. lat 60. zamyka i utrwala do końca PRL proces podporządkowywania instytucji przedszkoli założeniom panującej ideologii, w tym wizji zmonopolizowanej oświaty, w której co prawda przewidziano miejsce dla innych niż państwo podmiotów prowadzących placówki opiekuńczo-wychowawcze, ale zasadniczo regulacje w tym obszarze pozostały jedynie na ministerialnym papierze.

\section{Bibliografia}

Berendt G., Życie żydowskie w Polsce w latach 1950-1956. Z dziejów Towarzystwa SpolecznoKulturalnego Żydów w Polsce, Gdańsk 2006.

Borzymińska Z., Szkolnictwo Żydów w Polsce, w: Encyklopedia pedagogiczna XXI wieku, t. VI, T. Pilch (red.), Warszawa 2007.

Cała A., Datner-Śpiewak H. (oprac.), Dzieje Żydów w Polsce 1944-1968. Teksty źródłowe, Warszawa 1997.

Datner H., Po zagładzie. Społeczna historia żydowskich domów dziecka, szkót, kót studentów w dokumentach Centralnego Komitetu Żydów w Polsce, Warszawa 2016.

Dąbrowski A.G., Źródła do dziejów społeczności żydowskiej w Polsce w zasobie Archiwum Akt Nowych, w: Źródła archiwalne do dziejów Żydów w Polsce, B. Woszczyński, V. Urbaniak (red.), Warszawa 2001.

Dzieje Żydów w Polsce 1944-1968. Teksty źródtowe, oprac. A. Cała, H. Datner-Śpiewak, Warszawa 1997.

Grabski A., Centralny Komitet Żydów w Polsce (1944-1950). Historia polityczna, Warszawa 2015.

Kamińska K., Przedszkola, w: Encyklopedia pedagogiczna XXI wieku, t. IV, T. Pilch (red.), Warszawa 2005.

Kawalec G., Szkolnictwo żydowskie w Drugiej Rzeczypospolitej (1918-1939), „Rocznik Komisji Nauk Pedagogicznych" 2003, t. 56, s. 33-49.

Kendziorek P., Program i praktyka produktywizacji Żydów polskich $w$ działalności CKŻP, Warszawa 2016.

Kwiek J., Żydzi, Łemkowie, Stowacy w województwie krakowskim w latach 1945-1949/50, Kraków 2002.

Mirska Lasota H., Ucieczka od przeszłości, Montreal 2006.

Pańko G., Skotnicka-Palka M., Techmańska B. (red.), Młodzież w perspektywie edukacyjnej, spoŁecznej i kulturowej, Wrocław 2004.

\footnotetext{
58 Oświadczenie Rządowe z 16 X 1964 r. w sprawie ratyfikacji przez Polskę Konwencji w sprawie zwalczania dyskryminacji w dziedzinie oświaty, sporządzonej w Paryżu 15 XII 1960 r., Dz.U. 1964, nr 40, poz. 269.
} 
Pogorzała E., Działalność oświatowo-wychowawcza żydowskich kongregacji wyznaniowych w Polsce $w$ drugiej polowie lat 40-tych $X X$ w., „Facta Simonidis. Zeszyty Naukowe Państwowej Wyższej Szkoły Zawodowej w Zamościu” 2008, nr 1, s. 175-190.

Pogorzała E., Mniejszości narodowe i etniczne w polityce oświatowej państwa polskiego w latach 1944-1966, Zamość 2009.

Pogorzała E., Problem upaństwowienia szkót Centralnego Komitetu Żydów w Polsce w latach 1945-1949, „Przegląd Historyczno-Oświatowy” 2005, nr 1/2, s. 51-68.

Pogorzała E., Szkolnictwo hebrajskie w Polsce w latach 1946-1949, „Przegląd Historyczno-Oświatowy" 2006, nr 3/4, s. 137-156.

Rusiniak-Karwat M., Nowe życie na zgliszczach. Bund w Polsce w latach 1944-1949, Warszawa 2016.

Seidman H. (zebr. i oprac.), Żydowskie szkolnictwo religijne w ramach ustawodawstwa polskiego, Warszawa 1937.

Wiśniewska J., Przedszkola i ochronki zakonne w świetle polskiego prawa oświatowego $w$ latach 1945-1961, „Studia z Prawa Wyznaniowego” 2015, t. 18, s. 311-319.

Zieliński K., Szkolnictwo żydowskie w Polsce w latach 1918-1939, „Almanach Historyczny” 2003, t. 5, s. 211-255. 